\title{
STUDY OF THE DURATION AND IMMERSION DEPTH OF PURSLANE WEEDS AT GERMINATION TEMPERATURES OF 30C AND 40C AGAINST THE VIABILITY OF PURSLANE (PORTULACA OLERACEA L.) SEEDS
}

\author{
Abdullatif Zauzah*, Melati Rima \\ University of Khairun, Ternate, Indonesia \\ *E-mail: zauzahlatif@gmail.com
}

\begin{abstract}
Purslane weeds growth control can be conducted preventively since germination stage. This study aims to determine the duration and immersion depth of purslane weeds to find information about the seeds' viability at different germination temperatures. The research observed two factors, namely the durations of immersion at 2, 4, 6. And 8 weeks, and the depths of immersion at $0,5,10$, and $15 \mathrm{~cm}$. The experiment method and germination test used randomized factorial design with three repetitions and were continued with least significance difference (LSD) test. The results of the research showed that the interaction between the duration and the immersion depth of purslane weeds significantly affected the germination percentage, germination rates, and germination synchronization at the temperatures of $30 \mathrm{C}$ and $40 \mathrm{C}$. The longer and the deeper the seeds immersed, the lower the viability of the purslane weeds seeds was. The growth control of purslane weeds can be conducted by reducing the seeds germination.
\end{abstract}

\section{KEY WORDS}

Purslane, immersion, seeds, viability.

Weeds pose as competitors for cultivated crops in the acquisition of nutrients and can threat the productivity of crops by as much as $16-80 \%$. Weed growth control needs to be performed in order to minimize the decrease of crop productivity. Weed control can be carried out by considering the composition, the density, and the immersion of weed seeds (Siahaan et al., 2014). In addition, the ecology and biology of weeds and their effects are the basis for the study in weed control, requiring thorough observation (Paiman, 2012). A study on the immersion duration and depth of purslane seeds needs to be done to determine the potential of germination as the initial growth of weeds.

Purslane is a dry land weed that grows well in open areas and can decrease the productivity of local Topo onion (Soamole et al., 2018). One of the properties possessed by weeds in general is the ability to survive and regenerate. Purslane's survival strategy is characterized by the production of many seeds and vegetative organs that are able to grow and develop in critical environmental conditions (Proctor et al., 2011). Purslane weeds can produce approximately 135,917 seeds from one individual plant in one season with $50 \%$ water availability. Purslane has succulent stems that have the ability to survive in water shortage (Abdullatif, Z., ${ }^{2016}$ ). The abundance of seed production makes this plant spread quickly and can easily control agricultural land. In addition, the dormant seeds of purslane seeds last a short period of time which means they only require three days to germinate again.

The study of purslane weed's ability in utilizing existing resources to complete their life cycle, starting from the viability of seeds and growth, as well as the influence of other factors that interfere with their growth is necessary. The essence of purslane weed control is to suppress the growth of purslane seeds during germination, so that it can inhibit growth. One method of preventive control is to assess the depth of the purslane seed bank, assuming that the deeper the seeds are embedded the more the chance for purslane growth to be inhibited. As explained by Munthe et al. (2016), the more Eleusine indica L. Gaertn weed seeds are immersed, the fewer the number of seeds grow. Eleusine indica L. Gaertn weed seeds are resistant biotypes and paraquat sensitive biotypes at different depths, which tend to show 
decreasing amounts of sprouts at deeper depth (Tampubolon et al., 2014). Seed plants growing around secondary forest in Unmul Samarinda are classified as weed plants which commonly thrive more at $0-5 \mathrm{~cm}$ depth compared to other types of weed seeds growing at 5$15 \mathrm{~cm}$ depth (Azizah et al., 2015)

Purslane also has a different range of germination temperatures like any other weeds. Crassocephalum crepidioides, Conyza canadensis, and Ageratum conyzoides have a temperature range that allows high germination percentage, which are between $15^{\circ} \mathrm{C}$ and $30^{\circ} \mathrm{C}$, with germination for $A$. Conyzoides inhibited at $35^{\circ} \mathrm{C}$ (Yuan and Wen, 2018). Increasing the temperature from $25^{\circ} \mathrm{C}$ to $35^{\circ} \mathrm{C}$ improves the percentage of germination of $T$. portulacastrum from $65 \%$ to $85 \%$ (Tanveer et al., 2013). Meanwhile, Abutilon theophrasti germinates at temperatures between $10 \mathrm{C}$ to $40 \mathrm{C}$ and the germination is significantly affected by the immersion depth with germination percentages of $78.1-85.6 \%$ and planting depth of 1$4 \mathrm{~cm}$ (Xiong et al., 2018)

\section{MATERIALS AND METHODS OF RESEARCH}

The experiment was carried out in the experimental garden of the Faculty of Agriculture at Khairun University and the germination test was conducted at the Laboratory of the Faculty of Agriculture, Khairun University, from August to December 2018. The treatment consisted of two factors. The first factor was the duration of planting of purslane seeds in the soil (W), which was divided into 2, 4, 6 and 8 week periods and the second factor was the depth of the soil surface $(\mathrm{K})$, consisting of $0,5,10$ and $15 \mathrm{~cm}$ depth observations. The combinations of treatment were 16 treatments which were repeated 3 times using randomized factorial design. Analysis of variance was used to determine the real effect of each combination of treatment and was continued with the smallest real difference using the GenStat software 12.1. The material used was purslane seeds that had been prepared in the experimental garden with a criterion of the seeds being ripe, marked by the shiny black color of the seeds. Other important materials in this study were the seed bags and filter papers for sprout test. The tools used were germinator, thermometer, Petri dishes, and tweezers.

The soil was hoed according to the immersion depth treatment. The seeds were immersed according to the treatment marked with treatment labels tied to the end of the seed bags. The germination test was carried out periodically according to the treatment treated previously at $30 \mathrm{C}$ and $40 \mathrm{C}$ germination temperatures. Germination was tested using the Paper Test method. Petri dishes with a diameter of $12 \mathrm{~cm}$ were coated with 3 sheets of round shaped filter papers. A hundred (100) seeds were spread in each cup and repeated 3 times. The petri dishes were closed and placed inside a germinator. The observed variables consisted of percentage of seed germination (\%), germination rates, and germination simultaneity/synchronization (\%) using formulas based on Sutopo (2014).

Germination percentage calculated from day 3 to day 14 .

$$
\text { Germination Percentage }=\frac{\text { Total normal germination }}{\text { Total tested seeds }} \times 100 \%
$$

Total days until the appearance of radicle or plumule:

$$
\begin{aligned}
\text { Germination rate } & =\underline{\mathrm{N} 1 \mathrm{~T} 1+\mathrm{N} 2 \mathrm{~T} 2+\ldots \ldots \ldots \ldots \ldots \ldots \ldots \mathrm{NiTi}} \\
\text { Total germinating seeds } &
\end{aligned}
$$

Where: $\mathrm{N}=$ Total germinating seeds in a certain time measurement; $\mathrm{T}=$ Total time between the beginning of test to the end of certain interval in an observation.

The ability of a seed to germinate simultaneously after a certain period of germination and is calculated by the percentage of normal sprouts growing vigorously in a day between observation times 1 and 2 in the germination level test, which are the first observation time (3 days after planting) and the second observation time (11 days after planting). Criteria for sprouts with perfect growth were characterized by well-developed roots, stems, cotyledons of 
leaves, and shoot buds which are stronger than normal seeds, with formula as follow (Sadjad, 1993).

Simultaneous germination rate $=\frac{\text { Total strong germination }}{\text { Total germinated seeds }} \times 100 \%$

\section{RESULTS AND DISCUSSION}

The results showed that the immersion duration and depth of purslane seeds had a significant effect on the percentage of germination, germination rates, and synchronization/simultaneity of germination on purslane seeds. Germination at $30 \mathrm{C}$ is presented in Table 1.

Table 1 - The interaction between Immersion Duration and Depth of Purslane Seeds in Soil Germinated at 30C Temperature and Germination of Purslane Seeds

\begin{tabular}{|c|c|c|c|c|c|c|c|c|}
\hline Treatment & \multicolumn{8}{|c|}{ Immersion Depth } \\
\hline \multirow{2}{*}{ Immersion Duration } & $\mathrm{K} 1(0 \mathrm{~cm})$ & & $\mathrm{K} 2(5 \mathrm{~cm})$ & & $\mathrm{K} 3(10 \mathrm{~cm}$ & & K4 $(15 \mathrm{~cm}$ & \\
\hline & \multicolumn{8}{|c|}{ Germination Percentage } \\
\hline W1 (2 weeks) & $\begin{array}{c}7.00 \\
A\end{array}$ & $\mathrm{a}$ & $\begin{array}{c}6.67 \\
\text { A }\end{array}$ & $a$ & $\begin{array}{c}4.33 \\
A\end{array}$ & $\mathrm{a}$ & $\begin{array}{c}3.33 \\
A\end{array}$ & $\mathrm{a}$ \\
\hline W2 (4 weeks) & $\begin{array}{c}22.00 \\
B\end{array}$ & $\mathrm{a}$ & $\begin{array}{c}22.00 \\
B\end{array}$ & a & $\begin{array}{c}21.00 \\
B\end{array}$ & $\mathrm{a}$ & $\begin{array}{c}18.00 \\
C\end{array}$ & a \\
\hline W3 (6 weeks) & $\begin{array}{c}40.33 \\
\text { C }\end{array}$ & $\mathrm{C}$ & $\begin{array}{c}23.67 \\
\text { B }\end{array}$ & $b$ & $\begin{array}{c}21.67 \\
B\end{array}$ & $a b$ & $\begin{array}{c}13.67 \\
\text { BC }\end{array}$ & a \\
\hline W4 (8 weeks) & $\begin{array}{c}96.67 \\
D\end{array}$ & $\mathrm{c}$ & $\begin{array}{c}95.00 \\
\text { C }\end{array}$ & c & $\begin{array}{c}59.33 \\
\text { C }\end{array}$ & $\mathrm{b}$ & $\begin{array}{c}6.00 \\
\text { AB }\end{array}$ & a \\
\hline LSD 0,05 & 8.11 & & & & & & & \\
\hline Immersion Duration & \multicolumn{8}{|c|}{ Germination Rates } \\
\hline W1 (2 weeks) & $\begin{array}{c}7.07 \\
\text { A }\end{array}$ & $\mathrm{a}$ & $\begin{array}{c}7.44 \\
\text { A }\end{array}$ & $\mathrm{a}$ & $\begin{array}{c}12.46 \\
C\end{array}$ & $\mathrm{~b}$ & $\begin{array}{c}13.69 \\
\text { C }\end{array}$ & $\mathrm{b}$ \\
\hline W2 (4 weeks) & $\begin{array}{c}8.37 \\
A B\end{array}$ & $\mathrm{a}$ & $\begin{array}{c}9.38 \\
B\end{array}$ & a & $\begin{array}{c}8.80 \\
A\end{array}$ & $\mathrm{a}$ & $\begin{array}{c}8.60 \\
A\end{array}$ & a \\
\hline W3 (6 weeks) & $\begin{array}{c}8.94 \\
\text { BC }\end{array}$ & $a b$ & $\begin{array}{c}9.46 \\
\text { B }\end{array}$ & $\mathrm{b}$ & $\begin{array}{c}8.67 \\
\text { A }\end{array}$ & $a b$ & $\begin{array}{c}7.94 \\
\text { A }\end{array}$ & a \\
\hline W4 (8 weeks) & $\begin{array}{c}9.76 \\
\text { C }\end{array}$ & $\mathrm{a}$ & $\begin{array}{c}9.56 \\
\text { B }\end{array}$ & a & $\begin{array}{c}10.43 \\
B\end{array}$ & $\mathrm{a}$ & $\begin{array}{c}10.22 \\
\text { B }\end{array}$ & a \\
\hline LSD 0,05 & 1.30 & & & & & & & \\
\hline Immersion Duration & \multicolumn{8}{|c|}{ Simultaneous Germination (\%) } \\
\hline W1 (2 weeks) & $\begin{array}{c}4.00 \\
A\end{array}$ & $\mathrm{a}$ & $\begin{array}{c}3.67 \\
\text { A }\end{array}$ & $\mathrm{a}$ & $\begin{array}{c}3.33 \\
\text { A }\end{array}$ & $\mathrm{a}$ & $\begin{array}{c}2.33 \\
A\end{array}$ & $\mathrm{a}$ \\
\hline W2 (4 weeks) & $\begin{array}{c}9.00 \\
\mathrm{~A}\end{array}$ & $\mathrm{a}$ & $\begin{array}{c}9.67 \\
B\end{array}$ & a & $\begin{array}{c}7.00 \\
A B\end{array}$ & $\mathrm{a}$ & $\begin{array}{c}9.00 \\
B\end{array}$ & a \\
\hline W3 (6 weeks) & $\begin{array}{c}19.67 \\
\text { B }\end{array}$ & $\mathrm{b}$ & $\begin{array}{c}8.00 \\
A B\end{array}$ & a & $\begin{array}{c}8.67 \\
B\end{array}$ & $a$ & $\begin{array}{c}10.67 \\
B\end{array}$ & a \\
\hline W4 (8 weeks) & $\begin{array}{c}43.33 \\
\text { C }\end{array}$ & $\mathrm{c}$ & $\begin{array}{c}56.00 \\
C\end{array}$ & $\mathrm{~b}$ & $\begin{array}{c}27.67 \\
\text { C }\end{array}$ & $d$ & $\begin{array}{c}3.00 \\
\mathrm{~A}\end{array}$ & a \\
\hline LSD 0,05 & 5.22 & & & & & & & \\
\hline
\end{tabular}

Notes: Average figures in the same column followed by the same upper-case letters and in the same row followed by lower-case letters showed no significant difference in the LSD 0.05 test.

The 2 and 4 week immersion durations did not show any significant difference against the percentage of germination of purslane seeds in all immersion depths, while the lowest percentage of germination was at 2 weeks immersion duration and all immersion depths. The 6 and 8 weeks immersion durations gave a different effect compared to the other depths, reaching the highest percentage at $40.33 \%$ ( 6 weeks) and $96.67 \%$ ( 8 weeks). The deeper the immersion, the smaller the percentage of germination. Conversely, the longer the duration, the greater the percentage of germination at a depth of 0.5 , and $10 \mathrm{~cm}$. Purslane seeds in $15 \mathrm{~cm}$ depth and 2 weeks of immersion gave the lowest percentage (3.33\%), while the germination rate in $5 \mathrm{~cm}$ depth with 4-6 weeks immersion was not significantly different. However, there was a significant difference between seeds with 2 week immersion and $0 \mathrm{~cm}$ depth with the lowest value. Seeds in 10 and $15 \mathrm{~cm}$ depths showed the highest germination rates. Seeds with 4 week immersion at all depth levels showed the same effect in both treatments. Seeds in 6 week immersion at a depth of $5 \mathrm{~cm}$ showed the highest germination rate and it was different with the seeds immersed at the depth of $15 \mathrm{~cm}$ which had the 
smallest germination rate. Seeds in 8 week immersion showed the same germination rate at all immersion depth levels. The longer the seeds were buried at $0-15 \mathrm{~cm}$ depth, the longer the time needed to germinate. Likewise, the rate of germination would be fast if the seeds were in the depths of $10 \mathrm{~cm}$ with a shelf life of 2 weeks (Table 1).

The duration and the depth of immersion showed that purslane weeds exposed above the ground at $0-5 \mathrm{~cm}$ depth for 8 weeks and germinated at $30 \mathrm{C}$ had a high germination percentage at $90-95 \%$ with a fast germination rate (germination time of about 9 days) and synchronization level of $43-56 \%$ at depths of 0 and $5 \mathrm{~cm}$. The synchronization of germination below $40 \%$ was less vigorous, while that of above $70 \%$ had high vigor. The greatest synchronization level was at 4 weeks immersion on the ground surface of $0 \mathrm{~cm}(43.33 \%)$, and $10 \mathrm{~cm}$ depth (56\%). Seeds with simultaneous germination at a temperature of $30 \mathrm{C}$ were classified as seeds with less vigor.

Purslane seeds that were stored for a long time in the soil have higher viability which was characterized by percentage, rate, and simultaneity of germination. The length of immersion in soil was influenced by the viability of germination of weeds at 30C. Purslane seeds have a long dormant nature when immersed in the soil for a long period of time. This condition occurs because other germination factors such as light and oxygen are not met. This study is similar to previous studies on Cereus pernambucensis seeds that cannot germinate maximally when germinated in dark conditions (Socolowski et al., 2010). The seeds with the highest germination rate was Moringa oleifera seeds at night/day temperatures of 20/30C (Muhl et al., 2011).

The results of variance test showed that there was a significant effect on the previous treatment and the immersion depth of purslane weed seeds at $40 \mathrm{C}$ temperature to germination percentage, germination rates, and germination simultaneity.

Purslane seeds that were planted at $40 \mathrm{C}$ temperature with a duration of 2 weeks in 10 $\mathrm{cm}$ and $15 \mathrm{~cm}$ depths showed the lowest percentage of germination, respectively at $(13.67 \%)$ and $(11.33 \%)$. The highest percentage of germination was yielded by seeds planted for 8 weeks in $0 \mathrm{~cm}(98.67 \%), 5 \mathrm{~cm}(98.33 \%)$, and $10 \mathrm{~cm}$ (98.00\%) depths. Contrastingly, in $15 \mathrm{~cm}$ depth and 4 week duration, the germination rate was not different from that of 8 weeks. The germination rate at $40 \mathrm{C}$ showed that 2 weeks of immersion with a depth of $5 \mathrm{~cm}$ treatment resulted in the lowest germination rate. Immersions at 2, 4 and 8 week durations in the depth of $0 \mathrm{~cm}$ were not different from that of $15 \mathrm{~cm}$ depth. Seeds at 15 $\mathrm{cm}$ immersion depth resulted in the longest lasting germination rate (12.18). The deeper the immersion of seeds in the soil, the longer the germination rates, which was indicated by the significant number of germination rates (Table 2).

The lowest rates of germination synchronization were obtained from seeds with immersion duration of 2 weeks in all immersion depths. Most of the synchronization rates were above $40 \%$ synchronization value. The biggest simultaneous germination rate was above $70 \%$ at 8 weeks of immersion duration with $5 \mathrm{~cm}(80.33 \%)$ and $10 \mathrm{~cm}(73.67 \%)$ depths. Simultaneous germination rates with value above $70 \%$ showed that seeds had strong growth vigor. Thus, it can be stated that the temperatures affected and could increase the germination of purslane seeds.

Germination at a temperature of $40 \mathrm{C}$ resulted in increased percentage of germination rate by $98 \%$ in the depth of $0-10 \mathrm{~cm}$ and $69 \%$ in the depth of $15 \mathrm{~cm}$. Considering that purslane seeds have a planting depth limit to germinate, any increase in the depth of precipitation can potentially reduce the percentage of germination, the rate of germination, and the simultaneity of germination. The depth of seed immersion causes secondary dormancy because of germination factors such as light and soil temperature are not fulfilled. There are similar studies, such as the study on Crotalaria brevidens seeds which showed that each increase in planting depth caused a decrease in the number of seeds appearing per day (Opande et al., 2017), the depth of the immersion in Convolvulus arvensis L. (Asgharipour, 2011), and germination of Ceratocarpus arenarius with a minimum system/without immersion could accelerate germination (Ebrahimi and Eslami, 2011).

The germination rate increased in all treatments which showed that the longer the seeds were planted, the higher the increase of germination rate was. Therefore, it can be 
concluded that purslane seeds are seeds that have a long lasting dormant ability in the soil. The dormant phase will end if the seed is on the ground up to $15 \mathrm{~cm}$ deep. Purslane seeds can last long and are viable in soil and above the ground. However, the storage/immersion duration in the soil is influenced by the temperature at the time of germination with an indicator of increasing germination viability. Thus, it can be said that purslane seeds exposed to sunlight with weather fluctuations that change day and night, while the soil temperature on the surface ranges from $29-45 \mathrm{C}$ for $0-8$ weeks are still able to germinate with sprouts percentage of $7 \%$ at temperature (30C) and will be able to reach an increase in germination rate to $45.33 \%$ at $40 \mathrm{C}$ temperature.

Table 2 - Interaction between Immersion Duration and Depth of Purslane Seeds in Soil Germinated at $40 \mathrm{C}$ Temperature and Germination of Purslane Seeds

\begin{tabular}{|c|c|c|c|c|c|c|c|c|}
\hline \multirow{2}{*}{ Treatment } & \multicolumn{8}{|c|}{ Immersion Depth $(\mathrm{cm})$} \\
\hline & $\mathrm{K} 1(0 \mathrm{~cm})$ & & $\mathrm{K} 2(5 \mathrm{~cm})$ & & K3 $(10 \mathrm{~cm}$ & & $\mathrm{K} 4(15 \mathrm{~cm})$ & \\
\hline Immersion Duration & \multicolumn{8}{|c|}{ Germination Percentage (\%) } \\
\hline W1 (2 weeks) & $\begin{array}{c}45.33 \\
A\end{array}$ & $\mathrm{~b}$ & $\begin{array}{c}36.33 \\
A\end{array}$ & $\mathrm{~b}$ & $\begin{array}{c}13.67 \\
A\end{array}$ & $\bar{a}$ & $\begin{array}{c}11.33 \\
A\end{array}$ & $\mathrm{a}$ \\
\hline W2 (4 weeks) & $\begin{array}{c}71.33 \\
B\end{array}$ & a & $\begin{array}{c}87.67 \\
\text { B }\end{array}$ & b & $\begin{array}{c}90.00 \\
\text { C }\end{array}$ & b & $\begin{array}{c}78.67 \\
\text { C }\end{array}$ & $a b$ \\
\hline W3 (6 weeks) & $\begin{array}{c}97.00 \\
\text { C }\end{array}$ & c & $\begin{array}{c}96.67 \\
\text { B }\end{array}$ & c & $\begin{array}{c}72.33 \\
B\end{array}$ & b & $\begin{array}{c}50.33 \\
B\end{array}$ & a \\
\hline W4 (8 weeks) & $\begin{array}{c}98.67 \\
\text { C }\end{array}$ & $b$ & $\begin{array}{c}98.33 \\
\mathrm{~B}\end{array}$ & b & $\begin{array}{c}98.00 \\
\text { C }\end{array}$ & b & $\begin{array}{c}69.00 \\
\mathrm{C}\end{array}$ & a \\
\hline LSD 0,05 & 13.52 & & & & & & & \\
\hline Immersion Duration & \multicolumn{8}{|c|}{ Germination Rates } \\
\hline W1 (2 weeks) & $\begin{array}{c}10.17 \\
A\end{array}$ & C & $\begin{array}{c}7.58 \\
A\end{array}$ & $\bar{a}$ & $\begin{array}{c}8.75 \\
A\end{array}$ & $\mathrm{~b}$ & $\begin{array}{c}10.69 \\
A\end{array}$ & C \\
\hline W2 (4 weeks) & $\begin{array}{c}11.35 \\
B\end{array}$ & c & $\begin{array}{c}10.55 \\
B\end{array}$ & $a b$ & $\begin{array}{c}9.98 \\
B\end{array}$ & a & $\begin{array}{c}11.21 \\
\mathrm{~A}\end{array}$ & $\mathrm{bc}$ \\
\hline W3 (6 weeks) & $\begin{array}{c}10.88 \\
A B\end{array}$ & a & $\begin{array}{c}10.75 \\
B\end{array}$ & a & $\begin{array}{c}10.96 \\
C\end{array}$ & a & $\begin{array}{c}12.18 \\
B\end{array}$ & $\mathrm{bc}$ \\
\hline W4 (8 weeks) & $\begin{array}{c}11.71 \\
B\end{array}$ & a & $\begin{array}{c}13.26 \\
C\end{array}$ & b & $\begin{array}{c}12.71 \\
\mathrm{D}\end{array}$ & b & $\begin{array}{c}11.33 \\
\mathrm{~A}\end{array}$ & a \\
\hline LSD 0,05 & 0.83 & & & & & & & \\
\hline Immersion Duration & \multicolumn{8}{|c|}{ Simultaneous Germination (\%) } \\
\hline W1 (2 weeks) & $\begin{array}{c}10.33 \\
A\end{array}$ & $\mathrm{a}$ & $\begin{array}{c}10.00 \\
A\end{array}$ & $\mathrm{a}$ & $\begin{array}{c}4.67 \\
\mathrm{~A}\end{array}$ & $\mathrm{a}$ & $\begin{array}{c}3.67 \\
\text { A }\end{array}$ & a \\
\hline W2 (4 weeks) & $\begin{array}{c}40.33 \\
B\end{array}$ & a & $\begin{array}{c}46.00 \\
B\end{array}$ & a & $\begin{array}{c}47.33 \\
\text { C }\end{array}$ & a & $\begin{array}{c}43.67 \\
\text { C }\end{array}$ & a \\
\hline W3 (6 weeks) & $\begin{array}{c}59.00 \\
C\end{array}$ & c & $\begin{array}{c}61.00 \\
C\end{array}$ & c & $\begin{array}{c}39.33 \\
B\end{array}$ & b & $\begin{array}{c}30.33 \\
B\end{array}$ & a \\
\hline W4 (8 weeks) & $\begin{array}{c}60.33 \\
\mathrm{C}\end{array}$ & $b$ & $\begin{array}{c}80.33 \\
\text { D }\end{array}$ & c & $\begin{array}{c}73.67 \\
\mathrm{D}\end{array}$ & c & $\begin{array}{c}34.00 \\
B\end{array}$ & a \\
\hline LSD 0,05 & 7.59 & & & & & & & \\
\hline
\end{tabular}

Notes: Average figures in the same column followed by the same upper-case letters and in the same row followed by lower-case letters showed no significant difference in the LSD 0.05 test.

The higher the temperature, the greater the absorption of water by the seeds and the higher the work of enzymes that remodel carbohydrates and stimulate the acceleration of germination, which affect the simultaneity of germination. The increased germination rates and simultaneity of germination make the purslane control the agricultural land quickly. The purslane seed's immersion duration is different from the seeds of Toona sureni which only last for four weeks in the soil and after reaching $46 \%$ simultaneous germination, and after a period of two weeks immersion, seed's viability decreases by $20 \%$ (Nurhasybi, 2016).

\section{CONCLUSION}

The immersion duration and depth of purslane seeds could affect seed's viability. The seeds which were immersed for two months in the soil still germinated with germination percentage of $98 \%$ if the seeds were to be immersed in the depth of $0-10 \mathrm{~cm}$, while the viability of the seeds began to decrease at immersion depth of $15 \mathrm{~cm}$. In addition, germination was also influenced by temperatures, in which at a temperature of $40 \mathrm{C}$ the germination rates, percentage, and simultaneity were higher than those at 30C. Because of 
this, soil cultivation by reversing the soil to the surface and maintaining the temperature of the soil can accelerate the growth of purslane weeds.

\section{REFERENCES}

1. Abdullatif.,Z. 2016. Effect of Cutting and Watering of Portulaca aleracea L. on Weeds Control, International Journal of Plant Research, 6 (1): 1 - 6.

2. Asgharipou, R.A., 2011. Effects of Planting Depth on Germination and the Emergence of Field Bindweed (Convolvulus arvensis L.), Asian J. of Agr. Sciences, 3(6): 459-461.

3. Azizah, C., D. Susanto and M. Hendra, 2015. The Potential Seed's Reserves at Soil Depth of $0-15$ at Different Area in Secondary Forests in Botanical Garden Unmul Samarinda, Proceeding FMIPA Unmul Seminar Science and Technology, Vol. 1 No. 1 September 2015, Samarinda, Indonesia.

4. Ebrahimi, E and S. V. Eslami, 2012. Effect of Environmental Factors on Seed Germination and Seedling Emergence of Invasive Ceratocarpus arenarius, Article in Weed Research, Faculty of Agriculture, Birjand University, Birjand, Iran.

5. Golzardi, F., 2014. Effect of Different Constant and Alternative Temperatures and Light Situations on Germination Behavior of Two Purslane (Portulaca oleracea L.) Populations, International Journal of Natural Sciences, 4(2): 13- 21.

6. Muhl, Q.E., 2011. Temperature Effect on Seed Germination and Seedling Growth of Moringa oleifera Lam., Seed Science and Technology (Article), 39: 208-213.

7. Munthe, A. S., E. Purba and R. R. Lahay, 2016. Germination Seed Response of Eleusine indica L. Gaertn to Depth and Buried Time, Jurnal Agroekoteknologi, 4 (4): 2367-2375.

8. Nurhasybi and D. J. Sudrajat, 2016. Determination of Seed Storability of Suren Merr in Natural Through (Toona sureni Merr.) Soil Seed Bank Storage, Jurnal Perbenihan Tanaman Hutan 4 (1): 33-41

9. Opande, G.T., D. M. Musyimi and K. C. Muthoni, 2017. Effects of Planting Depth on Seed Germination and Emergence of Crotalaria Brevidens on Maseno Soils Maseno (Kenya), Journal of Agriculture and Veterinary Science, 10 (8): 30-34.

10. Paiman, 2012. Variability of Weed commuiity on Various of Soil Depth, Agro UPY, 4(1): 23-32.

11. Proctor, C. A., R.E. Gaussoin and Z. J. Reicher, 2011. Vegetative Reproduction Potential of Common Purslane (Portulacaoleracea), BioOne Weed Technology, 25:694-697.

12. Sadjad, S. 1993. Dari Benih Kepada Benih. Grasindo, Jakarta. 144 hal

13. Siahaan, M.P., E. Purba and T. Irmansyah, 2014. Composition and Weed Seed bank Density at Various Soil Depth of Crop Planting area at Balai Benih Induk Tanjung Selamat, Jurnal Online Agroekoteknologi, 2(3): 1181-1189.

14. Soamole, F., Z. Abdullatif and H. The Influence of Growth Weed Purslane (Portulaca oleracea) of Growth and the Production of Onion plants (Allium ascalonicum) 'Topo', Scripta Biologica, 5 (1): 41-46.

15. Socolowski, F., D. C. M. Vieira, E. Simao and M. Takaki, 2010. Influence of Light and Temperature on Seed Germination of Cereus pernambucensis Lemaire (Cactaceae), Biota Neotrop., 10 (2): 53-56.

16. Sutopo, L., 2004. Teknologi Benih Edisi Revisi. PT. RajaGrafindo Persada. Jakarta.

17. Tampubolon, E. Purba, T. Chairun Nisa, 2014. Effect of Burial Depth, Nitrogen, and Paraquat on the Growth of Paraquat-Resistant and Susceptible Biotypes of Eleusine indica L. Gaertn, Jurnal Online Agroekoteknologi, 3(1): 08-19.

18. Tanveer. A., 2013. Effect of Ecological Factors on Germination of Horse Purslane (Trianthema portulacastru), Planta Daninha 31 (3): 587-597.

19. Xiong, R.C., 2018, Effects of Environmental Factors on Seed Germination and Emergence of Velvetleaf (Abutilon theophrasti), Planta Daninha 36: 1-13.

20. Yuan, X., 2018. Seed Germination Response to High Temperature and Water Stress in Three Invasive Asteraceae Weeds from Xishuangbanna, SW China, PlosOne 13(1):1-16.

21. Zhang, H., 2015. A Modified Thermal Time Model Quantifying Germination Response to Temperature for C3 and C4 Species in Temperate Grassland, Agriculture, 5: 412-426. 